\section{Induction, Philosophical Conceptions of}

John P. McCaskey

Columbia University, New York, NY, USA

\section{Abstract}

How induction was understood took a substantial turn during the Renaissance. At the beginning, induction was understood as it had been throughout the medieval period, as a kind of propositional inference that is stronger the more it approximates deduction. During the Renaissance, an older understanding, one prevalent in antiquity, was rediscovered and adopted. By this understanding, induction identifies defining characteristics using a process of comparing and contrasting.

Important participants in the change were Jean Buridan, humanists such as Lorenzo Valla and Rudolph Agricola, Paduan Aristotelians such as Agostino Nifo, Jacopo Zabarella, and members of the medical faculty, writers on philosophy of mind such as the Englishman John Case, writers of reasoning handbooks, and Francis Bacon.

\section{Synonyms}

epagōgē; inductio

(C) Springer Nature Switzerland AG 2020

M. Sgarbi (ed.), Encyclopedia of Renaissance Philosophy, https://doi.org/10.1007/978-3-319-02848-4_1054-2

\section{Heritage and Rupture with the Tradition}

An understanding of the earlier history of induction is essential to understanding induction in the Renaissance, for the story of induction in the Renaissance is the story of a slow rediscovery of an earlier - and to us unfamiliar - conception.

Aristotle said that what induction is, is obvious (Topics, 157a8). It is a proceeding from particulars to a universal (Topics, 105a13-4). But there is an ambiguity here. Does Aristotle mean particular and universal statements? Or does he mean particular things (or kinds of things) and universal concepts? Nowadays we presume the first, but Socrates, who Aristotle says introduced induction (epagogē), thought the second. In the Ion (540b-d), Socrates considered the helmsman, doctor, cowherd, wool-maker, and military general, and concluded that the master of any craft is one who knows its subject best. This was some sort of induction but not an inference from a complete or even incomplete enumeration. This was a compare-and-contrast process of determining what it means to say someone is a master. Once the process is completed, there is no worry that the next master will not know the craft well, for we have discovered that this is part of what it means to be a master. If a man does not know his material well, he is not a master. The universal claim is true by definition. But the definition is not arbitrary or stipulative. It is the conclusion of an inductive inquiry. (It is what Immanuel Kant said cannot exist, an analytic a posteriori.) When 
Aristotle said Socrates gets credit for inductive reasoning and universal definitions, Aristotle was listing not two unrelated discoveries but two perspectives on one cognitive operation. Aristotle's own methods for identifying formal cause, as in Book V of the Topics, are methods of Socratic induction. If Aristotle's Prior Analytics is about deduction, his Posterior Analytics is about induction, and induction of the Socratic sort. Cicero's view on induction, too, was Socratic. It was Cicero who coined the Latin term in-ductio, on the model of the Greek epagogee. He would have a large influence on induction in the Renaissance. Others in the ancient world agreed with Aristotle and Cicero. Indeed, the Socratic understanding of what induction is was conventional all through Greek, Hellenistic, and early Roman antiquity.

This understanding got switched around by the Neoplatonists of late antiquity. They read Aristotle's particulars and universals as about particular and universal statements, not particular things and universal concepts. The change started with Clement of Alexandria in the second century. He said that a definition is a summation and therefore that induction obtains force not by comparing and contrasting but by completely enumerating components. In Alexandria, around $500 \mathrm{AD}$, Ammonius Hermiae and his students Simplicius and John Philoponus incorporated Clement's view into their comprehensive reworking of Aristotle. In their Neoplatonic synthesis, induction can be reduced to a kind of deduction. The deduction has the form of a syllogism with a minor premise suppressed. The minor premise is the presumption that all particulars have been enumerated. (The proposal found support in Aristotle's Prior Analytics B 23, but only because the Alexandrians read that difficult chapter in a new way. All other mentions in Aristotle's corpus indicate Aristotle had a Socratic conception.)

The Alexandrian, Neoplatonic, non-Socratic understanding of induction was transmitted through the medieval period in both Latin and Arabic. In this conception, induction is a kind of propositional inference. That is, the particulars are not particular concepts or things but particular statements (e.g., this magnet attracts iron; that magnet attracts iron; the other magnet attracts iron) and the universals are universal statements (e.g., all magnets attract iron). And unless the enumeration is complete, the conclusion cannot be certain. While nowadays we use white swans and an Australian black swan to demonstrate the fragility of such induction, Scholastics used the jaws of animals: This animal chews by moving the lower jaw; that animal does; the other animal does. If we conclude that all animals chew by moving the lower jaw, the conclusion will be overturned when we discover the Nile crocodile, for it moves the upper jaw.

For an example of a reliable induction, Ockham (c. 1287-1347) used the Holy Trinity: What is true of Father, Son, and Holy Ghost is true of God. The enumeration is complete. Scholastics recognized that an incomplete enumeration could be made complete by adding et cetera to the list of particulars. Formally, this allowed the induction to be rendered as a deduction, but in practice of course it does not do much. Whether that et cetera is exhaustive is the very question at hand. (Ockham, Summa logicae, III.3.31-7)

In the Renaissance, the established, Alexandrian, Scholastic conception of induction was increasingly questioned.

Ockham's younger contemporary Jean Buridan (before 1300-c. 1360) claimed that with or without the et cetera, an induction by enumeration of particular statements is not really an induction at all, or at most it is just a special case. He espied in Aristotle's Posterior Analytics B 19 a completely different conception of induction. Here induction seems to be the process of coming to know universals in a hierarchical process of combining sensations to form memories, memories to form experiences, and experiences to form universals. By this we come to know that every fire is hot, that every magnet attracts iron, that all rhubarb purges bile, that everything that comes to be in nature comes to be from some preexisting subject, and so on for many other indemonstrable principles. These are known true not by extending a sufficiently long list of observation statements, but by discovering the very nature of fire, magnets, rhubarb, natural subjects, and so on. To make his point, Buridan used 
Socrates' example of the master in a discipline. (Buridan, Summulae, 6.1.4, 6.1.5, and 8.5.4)

Buridan had discovered the alternate conception of induction in Aristotle's Posterior Analytics but the conception is even plainer and more pervasive in Aristotle's Topics, the foundational text for a Renaissance approach to reasoning that scholars now call topics-logic. The humanists Lorenzo Valla (c. 1406-1457) and Rudolph Agricola (1443/4-1485) were influential advocates of this approach.

In induction, Valla mocked any attempt to get around a limited enumeration by adding et cetera or the like; indeed he mocked any attempt to treat induction as a defective sort of deduction. He insisted on returning to the views of induction advocated by Cicero and Socrates. Valla said Boethius (d. c. 526 AD), who had advocated the Neoplatonic Alexandrian conception, was like someone who has stolen a horse and tries to hide the theft by cutting and dyeing the horse's hair. What Boethius was peddling, Valla said, was simply not true induction. (Valla, Repastinatio, 3.16)

While Valla was dismissive, Agricola was accommodating. He sought a taxonomy that offered a place to both the Scholastic convention and the rediscovered ancient. He proposed to call the conventional inference enumeratio and to use inductio for the ancient, open-ended procedure. For the second, he treated Socrates, Cicero, and Aristotle's Topics as the authorities. (Agricola, De Inventione Dialectica, 2.18)

\section{Innovative and Original Aspects}

Buridan, Valla, Agricola, and other challengers did not immediately unseat the conventional understanding of induction. Buridan's writings on the subject barely circulated and were never printed. Although Valla criticized the conventional view of induction, he did not have much to say on the alternative. He died in 1457. Agricola died in 1485, his De Inventione Dialectica not yet printed. Into the $1480 \mathrm{~s}, 30$ years after the invention of printing, almost everything one would read on induction still presented the conventional Scholastic account whereby induction is a defective kind of syllogism made good by complete enumeration, actual or presumed.

But during the 1480s newly published texts began to undermine that account. In 1484, all of the Socratic dialogues became available in Marsilio Ficino's new Latin translation. It thus became easier to see what Aristotle meant when he said Socrates introduced induction. In the 1490s, commentaries on Aristotle became more comprehensive. New attention to the Posterior Analytics and the Topics disrupted long-held views of what Aristotle had thought about induction. Editions of Cicero's Topics, with its plainly Socratic view of induction, were frequently printed. Valla's Repastinatio Dialectice et Philosophie came into print. Agricola's De Inventione was published in 1515. By the 1540s, students of induction were faced with multiple traditions and inconsistent interpretations. While Aristotle had said that what induction is, is obvious, the Renaissance Paduan Agostino Nifo, in a commentary on the Topics published in 1535 and several times thereafter, disagreed. He noted that the very nature of induction was now in dispute (Nifo, 1.68).

The tension is evident in logic textbooks in England. Since Peter of Spain's Tractatus of the mid-thirteenth century, induction had a conventional place in logic textbooks. It was treated briefly, as a derivative of deduction, along with enthymeme and example. After extended treatment of the syllogism, induction would get a few short paragraphs, maybe one page. John Seton's Dialectica, first published in London in 1545 was different. The treatment of induction was three pages long, wide-ranging, and eclectic. Seton began conventionally enough but then introduced newer examples, one that the Protestant Philipp Melanchton (1497-1560) had recently used. Seton added the requirement that in a valid induction, no counter examples be observed. He compared induction to deduction in ways Aristotle had. He echoed remarks Agricola had made and reported on Agricola's proposal to use the word enumeratio. He brought in the new topicslogic and cited Cicero and Plato. Nearly all the traditions and subtraditions on induction made an appearance in this one place, but Seton 
made no attempt to integrate them. (Seton, "De Inductione," Dialectica)

Thomas Wilson tried. His Rule of Reason was the first logic textbook in English. The first edition was published in London in 1551 and except for characteristically Protestant examples and use of some of Agricola's language, what Wilson said about induction in that edition was not particularly unusual. This changed, however, with the second edition, "newly corrected," printed only 1 year later, in 1552. In its treatment of induction, Wilson added a second section, larger than all of his original treatment, on what he said is another kind of induction, one that the learned call Socrates' induction. The presentation, while not particularly insightful, echoes Agricola and tries to incorporate the developing enthusiasm for the new alternative to Scholastic induction. (Wilson, Rule of Reason, 1551, "Inductio"; 1552, "Inductio," fol. 66.)

Such enthusiasm was growing in Padua among the medical faculty. William Harvey, a student at Padua in 1600 , called the medical faculty's new method regula Socratis, the rule of Socrates. His teachers understood it as a revival of ideas Aristotle had developed in his biological works and in the Posterior Analytics. Using this method, one formed universal statements by identifying the essence of something, and in the case of anatomical organs, this essence was the organ's function. Such essence was discovered by careful dissection and experimentation and a thoroughly Socratic process of comparing and contrasting. (Cunningham)

An opponent of this new inductive science was Jacopo Zabarella, professor of natural philosophy and Padua's most distinguished logician. In the early twentieth century, Ernst Cassirer and then John Herman Randall proposed that Zabarella's so-called regressus theory included an influential new theory of induction. A recently published modern edition and English translation of Zabarella's relevant works shows that induction played no significant role in regressus theory and what Zabarella had to say about induction was in fact designed to thwart advance of the new conception. (Zabarella)
In England, the new thinking on induction was bolstered by John Case in his logic textbook Summa veterum interpretum of 1584 and in his treatise Lapis Philosophicus of 1599. In the first, he brings Aristotle's four causes, including the formal cause (central to Socratic induction), into the discussion of induction, even if only perfunctorily. In the second, he explores the Aristotelian idea that abstract ideas are known at first only confusedly (confuse) and then, after sufficient cogitation, come to be known distinctly (distincte). What is important about Case's presentation is not the content, but the terminology. Notio (and its cognate notitia) are used more frequently than in the past. The term will be central for Bacon. Furthermore, Case calls the ill-formed abstractions known only confusedly "abstract phantasms" or "idols," another concept central for Bacon. (Case, 1584, 1.19; 1599, 1.1, 2.1.3)

Francis Bacon (1561-1626), one of the most influential writers on induction and scientific method in Western philosophy, entered a conversation that was already underway. His Novum Organum (1620) was cast in the language of that conversation. His contribution was to systematize and fully revive Socratic induction. In doing so, he brought to maturity the Renaissance reconceptualization of induction.

Bacon came to induction late and indirectly, for his initial interest was not primarily epistemological but practical. He sought some method by which someone could confidently make things that had never been made before. The method would need to ensure two things, what he called certainty and liberty. The first, Bacon thought, was easy, if one ignores the second. It takes no great genius or much method, for example, to know that heat melts butter (not Bacon's example; his involved making something white). The next dollop thrown on the skillet will melt. We can continue doing what we have always done, and we know what will happen. But what of cheese? What about wax? Clay? Will it behave the same? What about a new artificial material, envisioned but not yet produced? As we exercise our liberty, as we try things increasingly dissimilar, we lose our certainty - at least without a proper method. 
Bacon wanted a method that would allow liberty without sacrificing certainty.

To solve his problem Bacon turned to Aristotle's concepts of kata pantos and katholou proton. A property that is true kata pantos is true for all members of a class. But a property that is true katholou proton is true of all and only all members of a class. Thus a proposition predicating a katholou proton property is convertible; that is, subject and predicate can be swapped. All triangles have angles that sum to $180^{\circ}$, and any polygon whose angles sum to $180^{\circ}$ is a triangle. This suggests a rule: If you want a polygon whose angles sum to $180^{\circ}$, make a triangle. But even if the properties are katholou proton, the rule may not be useful. Having a flat surface, feeling smooth, appearing bright, and being able to see your face in it may all be katholou proton properties of a metal, but to make a metal all of these, you need to know which causes the others, or, to use Bacon's term, which is more "original." It is not enough to know that properties "cluster and concur"; it is important to identify which is the cause. But which cause? Bacon considers Aristotle's four. He dismisses the final cause as inapplicable in cases outside of human actions. And he thinks knowing just the material and efficient causes can provide certainty but not liberty. That knowledge helps only to "achieve new discoveries in material which is fairly similar." What is needed, Bacon says, is to identify the "form or formal cause." The formal cause is what makes something the kind of thing it is; it identifies the Socratic essence. Bacon says that "Aristotle's school" - by which he meant Scholastic advocates of the Neoplatonic Alexandrian Aristotelianism - was right "that there is no true knowledge but by causes, no true cause but the form, no true form known except one." But Aristotle's school misunderstood the form and consequently - and wrongly - regarded its discovery as hopeless. (Bacon 1857, p. 325)

A form, Bacon says, is merely a particular arrangement and motion of (frequently imperceptible) physical components. In Book 2 of the Novum Organum, Bacon presents a method for identifying that arrangement and motion. He says the search should begin with a comprehensive inventory of observed instances, related absences, and related variations. He offers 27 kinds of observations ("prerogatives") that are particularly valuable for discovering the essence or formal cause of something. When he uses his method to discover the formal cause of heat, he concludes that heat is a particular kind of motion of imperceptible particles. He then makes the remarkable claim:
If in any body you can arouse a motion ... [of this certain kind], you will certainly generate heat. It is irrelevant whether the body is elementary (so-called) or imbued with heavenly substances; whether luminous or opaque; whether rare or dense; whether spatially expanded or contained within the bounds of its first size; whether tending toward dissolution or in a steady state; whether animal, vegetable or mineral, or water, oil or air, or any other substance whatsoever. (Bacon 1620, book 2, aphorism 20, Silverthorne translation, fol- lowing Bacon's highlighting.)

From an analysis of particulars, Bacon came to a tremendously universal conclusion, one of both certainty and liberty. He came to call his method a kind of induction.

Bacon stresses that this particular kind of motion is not the efficient cause of heat, that is, it is not the case that there is one thing, the motion, that produces another thing, the heat. Rather the particular kind of motion is what heat is. If you can produce this kind of motion, you produce heat, because the motion and the heat are the same thing. Motion (the genus) and the particular kind of it (the species) define heat, but the definition is discovered not stipulated. Inductive science becomes the search for universal statements warranted by concepts properly defined by essential characteristics. Baconian "idols" are ill formed and poorly defined abstractions. Induction (of the Socratic type) provides the needed remedy.

For Bacon an induction is warranted not by positive instances that confirm, but by comparisons that contribute to the definition of the predicate. Finding that definition by this process of compare-and-contrast is the essence of Socratic induction. It was this to which Bacon referred when he said, "[The correct procedure] has not yet been done, nor even certainly tried except only 
by Plato, who certainly makes use of this form of induction to some extent in settling on definitions and ideas" (Bacon 1620, book 1, aphorism 105 , Silverthorne translation).

\section{Impact and Legacy}

Baconian induction became canonical in natural philosophy. An important early practitioner was Robert Boyle (1627-91), a candidate for the title of first modern chemist. He said the use of experimental induction to find the formal cause of chemical properties was the "noblest" and "most important" part of natural philosophy. In 1837, William Whewell looked back on 200 years of scientific progress and gave Baconian induction the credit. Even David Hume accepted the Baconian conception. He never used "induction" to name the object of his epistemological doubts. That is a recent attribution. It was only after John Stuart Mill's System of Logic (1843) that the Scholastic conception returned and again became standard. (Ducheyne and McCaskey)

Writers on induction in the Renaissance were not trying to solve the "problem of induction" that we talk about. If anything went by that name in Renaissance philosophy, it was merely the problem of how to form good abstractions and to define by essentials. The Renaissance project finished with Bacon's proposal on how to do so.

\section{References}

Agricola, Rudolph. 1515. De Inventione Dialectica. Louvain: Alost.

Bacon, Francis. 1620. Novum organum. In Instauratio magna. London: John Bill.

Bacon, Francis. 1857-1870. Valerius terminus. In vol. 3 of The collected works of Francis Bacon. Edited by James Spedding, Robert Leslie Ellis, and Douglas Denon Heath. London: Longmans \& Co.
Bacon, Francis. 2000. The New Organon, eds. Lisa Jardine and Michael Silverthorne. Cambridge University Press.

Boyle, Robert. 1999. The Origine of forms and qualities, according to the corpuscular philosophy. In vol. 5 of The works of Robert Boyle. Edited by Michael Hunter and Edward Davis. London: Pickering \& Chatto.

Buridan, Jean. 2001. Summulae de Dialectica. Trans: Gyula Klima. New Haven: Yale University Press.

Case, John. 1584. Summa veterum interpretum in universam dialecticam Aristotelis. London: Thomas Vautrollier.

Case, John. 1599. Lapis philosophicus seu commentarius in 8 libros physicorum Aristotelis in quo arcana physiologiae examinantur. Oxford: Joseph Barnes.

Cunningham, Andrew. 1985. Fabricius and the 'Aristotle project' in anatomical teaching and research at Padua. In The medical renaissance of the sixteenth century, ed. A. Wear, R.K. French, and I.M. Lonie. Cambridge: Cambridge University Press.

Ducheyne, S., and John P. McCaskey. 2014. "The sources of Mill's views of ratiocination and induction." In Mill's A System of Logic. Edited by Antis Loizides.

Jardine, Lisa. 1988. Humanistic logic. In The Cambridge history of renaissance philosophy. Cambridge: Cambridge University Press.

McCaskey, John P. 2014. Induction in the Socratic tradition. In Shifting the paradigm: Alternative perspectives on induction, ed. P.C. Biondi and L.F. Groarke. Berlin: De Guyter.

Nifo, Agostino. 1535. Aristotelis Stagiritae Topica inuentio in octo secta libros. Venice: Octavianus Scotus.

Ockham, William. 1967-1988. Opera philosophica et theologica, ed. Gedeon Gál et al. St. Bonaventure, NY: The Franciscan Institute.

Randall, John Herman. 1940. The development of scientific method in the school of Padua. Journal of the History of Ideas 1: 177-206.

Seton, John. 1545. Dialectica. London: Tho. Berthelet.

Valla, Lorenzo. 1982. Repastinatio dialectice et philosophie, ed. Gianni Zippel. Padua: Antenore.

Whewell, William. 1840. The history of the inductive sciences, from the earliest to the present time. London: John W. Parker.

Wilson, Thomas. 1551. The rule of reason, conteinyng the arte of logique, set forth in Englishe. London: Richard Grafton.

Zabarella, Jacopo. 2014. On methods and On regressus. Edited and translated by John P. McCaskey. I Tatti Renaissance Library, vols. 58 and 59. Cambridge, Mass./London: Harvard University Press. 